Plant Production Science

http:/www.journals.zu.edu.eg/journalDisplay.aspx?Journalld=1\&queryType=Master

\title{
MICROPROPAGATION OF SOME WATERMELON CULTIVARS BY USING TISSUE CULTURE TECHNIQUE
}

\author{
Maha S. Amer*, H.M. Arisha, A. Bardisi and Dalia A.S. Nawar \\ Hort. Dept., Fac. Agric., Zagazig Univ., Egypt
}

Received: 05/04/2020 ; Accepted: 23/04/2020

\begin{abstract}
This work was conducted at Laboratory of Tissue Culture, Hort. Dept., Fac. Agric., Zagazig Univ., Egypt, during the period from 2017 to 2018 to develop a protocol for micropropagation of two watermelon cultivars (Star and Romero) by using lateral buds as explant. Nodes of the two cultivars cultured on MS media containing different concentrations of benzyle adenine (BA) through multiplication stage. The highest shoot length was recorded on MS media containing $0.5 \mathrm{mg} \mathrm{BA} / 1$ for Romero cultivar, whereas lateral buds of Star cultivar which cultured on MS media containing 1.5 and $4 \mathrm{mg} \mathrm{BA} / 1$ showed the best No. of shoots and leaves/plantlet, respectively. The best results for roots formation percentage of Romero plantlets were MS media containing Indole bytric acid (IBA) at 1 or $1.5 \mathrm{mg} / 1$ followed by Naphthalene acetic acid (NAA) at 0.5 or $1 \mathrm{mg} / 1$ through rooting stage.
\end{abstract}

Key wards: Watermelon, Citrulls lanatus, in vitro, BA, IBA, rooting, multiplication

\section{INTRODUCTION}

Watermelon (Citrullus lanatus, Thumb.) which belongs to family cucurbitaceae, one of the important vegetable crops in Egypt. The major nutritional components of the fruit are carbohydrates, vitamin A and lycopene, an anticarcinogenic compound found in red flesh watermelon. Lycopene may help to reduce the risk of certain cancer of prostate gland, pancreas and stomach.

Regeneration of watermelon is largely depending on various factors such as genotype, explant types, explant ages and plant growth regulators. In vitro plant regeneration of watermelon has been reported using protocols for adventitious shoot regeneration from cotyledon segments (Srivastava et al., 1989; Compton and Gray, 1993). The system is based on three culture steps (Dong and Jia, 1991) a bud induction phase, culturing the explants in medium supplemented with cytokinin(Compton and Gray, 1993); an elongation phase, transferring the shoot buds to medium with a lower concentration of cytokinin (Dong and Jia, 1991) and a rooting phase, using

\footnotetext{
*Corresponding author: Tel. : +201099314210

E-mail address: maha2552010@gmail.com
}

a culture medium supplemented with auxin (Compton and Gray, 1994; Dabauza et al., 1997).

Sultana and Bari (2003) found that, in shoot tip explants of watermelon, the best shoot induction was observed in $\mathrm{MS}+1.0 \mathrm{mg} \mathrm{BA} / 1+$ $0.2 \mathrm{mg} \mathrm{NAA} / 1$. In the case of shoot tips culture, $100 \%$ of the explants developed shoot, number of shoots per culture was $6.10 \pm 0.15$ and average length of shoots per culture was $4.50 \pm$ 0.17 on the above medium. The combinations of BA with NAA were found superior to BA only and the combination of $1.0 \mathrm{mg} \mathrm{BA} / 1+0.2 \mathrm{mg}$ NAA/1 was superior to all other combinations of BA with NAA. Root formation was induced in the in vitro regenerated shoots by culturing them on half strength of MS medium with $0.1-1.0$ $\mathrm{mg} / \mathrm{l}$ either of NAA, IBA and IAA. Among the three types of auxin, NAA was found to be the most effective at different concentrations tested for producing roots on the cut margin of the shoot and $0.1 \mathrm{mg} \mathrm{NAA} / 1$ found to be the best concentration of auxin for proper rooting in which $100 \%$ shoots rooted within six weeks of culture. IBA is one of the most commonly used plant growth regulator for root induction in watermelon (Krug et al., 2005). 
Thakur et al. (2005) found that, full strength MS medium supplemented with auxin induced high frequency in root formation. Ahn et al. (2007) reported that high frequency of shoots rooted and grew normally on MS medium supplemented with IBA. The plantlets of watermelon which have well developed roots were successfully transplanted in soil and the percentage of survivability was $63.73 \%$.

Okumus et al. (2011) indicated that, a range of $0.5-1.0 \mathrm{mg} / \mathrm{l}$ of BA was almost equally effective in promoting the shoot length of cultures in the 3 genotypes. The highest percentage of rooting was achieved when medium supplemented with $1.0 \mathrm{mg} / 1$ of indole-3-butyric acid (IBA) which used for the three genotypes of watermelon.

Khalequzzaman et al. (2012) reported that maximum frequency (73\%) of shoot tip showed growth response in MS media supplemented with $5 \mathrm{mg} / \mathrm{l}$ benzyl adenine (BA) and $0.1 \mathrm{mg} / \mathrm{l}$ indole-3 acetic acid (IAA). Upon transfer to cytokinin-enriched medium, the cultures produced multiple shoots of watermelon and $2.0 \mathrm{mg} / 1 \mathrm{BA}$ was optimum in this respect. Rooting rate was $100 \%$ when shoots were obtained from second subculture which were cultured in medium with $1.0 \mathrm{mg} / 1$ indole-3 butyric acid (IBA). The shoots produced more roots with increasing number of subcultures.

Therefore, the aim of this work was to develop a protocol for micropropagation of two watermelon cultivars (Star and Romero) by using lateral buds through tissue culture technique.

\section{MATERIALS AND METHODS}

This work was conducted at Laboratory of Tissue Culture, Hort. Dept., Fac. Agric., Zagazig Univ., Egypt during the period from 2017 to 2018 to develop a protocol for micropropagation of two watermelon cultivars (Star and Romero) by using lateral buds as explant.

The experiment divided into two stages; i.e., multiplication and rooting. Seeds of two watermelon cultivars (Star and Romero) were obtained from Sand Valley Company at Ismailia Governorate, Egypt. Seeds were washed under running tap water for 1 hour and soaked in a soap solution for 5 minutes, then were taken and surface sterilized with $75 \%$ aqueous ethanol for
60 seconds, followed by 15 minutes in $20 \%$ of Clorox (sodium hypochlorite solution $\mathrm{NaClO}_{4}$ ) plus two drops of tween 20, as wetting agent, then rinsed four times (5 minutes each) by sterile distilled water and placed on sterilized filter paper (in culture cabinet) to remove the remained water.

\section{Culture Media}

Murashige and Skoog (MS) medium (Murashing and Skoog, 1962) was used in this work as shown in Table 1. Supplemented with $30 \mathrm{~g}$ sucrose $/ 1$ and solidified with $0.7 \%$ agar. The considered medium was supplemented with growth regulators according to the aim of each stage. $\mathrm{pH}$ was adjusted to 5.7 , then the medium was then sterilized in autoclave at $121^{\circ} \mathrm{C}$ for 20 minutes under $1.06 \mathrm{~kg} / \mathrm{cm}^{3}$ pressure. All cultures at the different stages were incubated in growth chamber at $25 \pm 2^{\circ} \mathrm{C}$ under $16 \mathrm{hr}$., photoperiod at an intensity of 2000 from cool white fluorescent lamps during germination, multiplication and rooting stage.

\section{Seeds Germination}

Seeds of two watermelon cultivars (Star and Romero) were cultured in jars containing MS basal medium without hormones, (Cortina and Culiáñez-Macià, 2004) and two seeds were cultured in each jar and kept for 25 days to get a sterilized seedlings as a source of explants for multiplication stage.

\section{Multiplication Stage}

The lateral buds, about 2-3 $\mathrm{mm}$ from the previously obtained seedlings were cultured on MS basal media supplemented with different concentrations of benzyl adenine (BA) at $0.5,1$, $1.5,2$ and $4 \mathrm{mg} \mathrm{BA} / / 1$. Five explants were cultured in each jar, the cultures were incubated for four weeks. Number of shoots per plantlet, shoot length $(\mathrm{cm})$ and number of leaves per plantlet and rooting initiation percentage were determined.

\section{Rooting Stage}

In vitro multiplicated shoots of watermelon cultivars (Star and Romero) were excised and cultured on MS medium supplemented with different concentrations of rooting growth regulators, naphthalene acetic acid (NAA) at 0.1, $0.5,1$ and $1.5 \mathrm{mg} / \mathrm{l}$ and indole butyric acid (IBA) at 
Table 1. Chemical composition of the used Murashige and Skoog basal nutrient medium

\begin{tabular}{|c|c|}
\hline$\overline{\text { Constituent }}$ & Concentration (mg/l) \\
\hline \multicolumn{2}{|l|}{ Macronutrients } \\
\hline $\mathrm{NH}_{4} \mathrm{NO}_{3}$ & 1650 \\
\hline $\mathrm{KNO}_{3}$ & 1900 \\
\hline $\mathrm{CaCl}_{2} \cdot 2 \mathrm{H}_{2} \mathrm{O}$ & 440 \\
\hline $\mathrm{MgSO}_{4} \cdot 7 \mathrm{H}_{2} \mathrm{O}$ & 370 \\
\hline $\mathrm{KH}_{2} \mathrm{PO}_{4}$ & 170 \\
\hline \multicolumn{2}{|l|}{ Micronutrients } \\
\hline $\mathrm{MnSO}_{4} \cdot 4 \mathrm{H}_{2} \mathrm{O}$ & 22.3 \\
\hline $\mathrm{ZnSO}_{4} .7 \mathrm{H}_{2} \mathrm{O}$ & 8.6 \\
\hline $\mathrm{H}_{3} \mathrm{BO}_{3}$ & 6.2 \\
\hline KI & 0.83 \\
\hline $\mathrm{Na}_{2} \mathrm{MoO}_{4} \cdot 2 \mathrm{H}_{2} \mathrm{O}$ & 0.25 \\
\hline $\mathrm{CuSO}_{4} .5 \mathrm{H}_{2} \mathrm{O}$ & 0.025 \\
\hline $\mathrm{CoCl}_{2} \cdot 6 \mathrm{H}_{2} \mathrm{O}$ & 0.025 \\
\hline \multicolumn{2}{|l|}{ Iron source } \\
\hline $\mathrm{Na}_{2}$ EDTA. $2 \mathrm{H}_{2} \mathrm{O}$ & 37.25 \\
\hline $\mathrm{FeSO}_{4} .7 \mathrm{H}_{2} \mathrm{O}$ & 27.85 \\
\hline \multicolumn{2}{|c|}{ Vitamins and amino acid } \\
\hline Glycine & 2.0 \\
\hline Nicotinic acid & 0.5 \\
\hline Pyridoxine-HCl & 0.5 \\
\hline Thiamine- $\mathrm{HCl}$ & 0.1 \\
\hline Myo-inositol & 100.0 \\
\hline
\end{tabular}

$0.2,0.5,1$ and $1.5 \mathrm{mg} / \mathrm{l}$. Rooting formation percentage, number of roots per plantlet, root length $(\mathrm{cm})$, and number of days for rooting initiation were determined after four weeks of sub culture.

\section{Statistical Analysis}

All treatments were arranged in a randomized complete block design system in three replicates. The obtained data were statistically analyzed according to Snedecor and Cochran (1980). The means were compared using the Duncan (1955) multiple rang test at 0.05 , probably.

\section{RESULTS AND DISCUSSION}

\section{Multiplication Stage}

\section{Effect of watermelon cultivars}

Results in Table 2 show that, there were significant differences between watermelon cultivars (Star and Romero) with respect to number of leaves/plantlet, shoot length, and number of shoots/plantlet. Star cultivar was regarded the highest values of number of both shoots and leaves/plantlet compared with Romero cultivar, whereas Romero cultivar was higher in shoot length. 
Table 2. Effect of cultivars and benzyl adenine (BA) concentrations on growth of watermelon plantlets during multiplication stage

\begin{tabular}{lcccc}
\hline Treatment & $\begin{array}{c}\text { Shoot length } \\
(\mathbf{c m})\end{array}$ & $\begin{array}{c}\text { Number of } \\
\text { shoots/plantlet }\end{array}$ & $\begin{array}{c}\text { Number of } \\
\text { leaves/ plantlet }\end{array}$ & $\begin{array}{c}\text { Rooting initiation } \\
(\%)\end{array}$ \\
\hline Cultivars & & & & \\
Star Cv. & $4.11 \mathrm{~b}$ & $5.84 \mathrm{a}$ & $24.97 \mathrm{a}$ & 100 \\
Romero Cv. & $6.75 \mathrm{a}$ & $4.69 \mathrm{~b}$ & $23.76 \mathrm{~b}$ & 100 \\
BA concentrations & & & & \\
$\mathbf{0 . 5} \mathbf{~ m g ~ B A} / \mathbf{l}$ & $6.62 \mathrm{a}$ & $5.49 \mathrm{~b}$ & $23.42 \mathrm{c}$ & 100 \\
$\mathbf{1 . 0} \mathbf{~ m g ~ B A} / \mathbf{l}$ & $5.58 \mathrm{bc}$ & $5.58 \mathrm{~b}$ & $22.00 \mathrm{~d}$ & 100 \\
$\mathbf{1 . 5} \mathbf{~ m g ~ B A} / \mathbf{l}$ & $3.98 \mathrm{~d}$ & $7.02 \mathrm{a}$ & $21.30 \mathrm{e}$ & 100 \\
$\mathbf{2 . 0} \mathbf{~ m g ~ B A} / \mathbf{l}$ & $6.08 \mathrm{ab}$ & $4.33 \mathrm{c}$ & $28.22 \mathrm{a}$ & 100 \\
$\mathbf{4 . 0} \mathbf{~ m g ~ B A} / \mathbf{l}$ & $4.87 \mathrm{c}$ & $3.91 \mathrm{~d}$ & $26.91 \mathrm{~b}$ & 100 \\
\hline
\end{tabular}

\section{Effect of BA concentrations}

Supplementing BA at $0.5,1,1.5,2$ and $4 \mathrm{mg}$ BA/1 to MS media, significantly increased shoot length, number of shoots/plantlet and number of leaves/plantlet (Table 2). Results indicated that, MS medium containing $2 \mathrm{mg} / \mathrm{l}$ BA gave the highest value for each of shoot length and number of leaves/plantlet, whereas BA at 1.5 $\mathrm{mg} / \mathrm{l}$ significantly increased number of shoots per plantlet compared with other treatments which didn't reflect any significant effect.

\section{Effect of the interaction between watermelon cultivars and BA concentrations}

Results in Table 3 show clearly that supplementing BA at $0.5 \mathrm{mg} / \mathrm{l}$ to $\mathrm{MS}$ medim recorded the highest value of shoot length of Romero cultivar, whereas adding BA at 1.5 and $4 \mathrm{mg} / \mathrm{l}$ gave the highest value for each of number of shoots/plantlet and number of leaves/plantlet of Star cultivar, respectively. From the foregoing results, it could be concluded that, supplementing BA at 0.5 or $1.5 \mathrm{mg} / 1$ were the best treatments for multiplication stage of watermelon cultivars. Okumus et al. (2011) indicated that a range of $0.5-1.0 \mathrm{mg} / 1$ of BA was almost equally effective in promoting the shoot length of cultures in the three watermelon genotypes (Surme, Beyazkis and Karakis).

\section{Rooting Stage}

\section{Effect of watermelon cultivars}

Results recorded in Table 4 show that Romero cultivar gave the highest number of roots/ plantlet, average root length and root formation (\%) compared to Star cultivar. Rooting percentage was 93.75 and $88.12 \%$ for Romero and Star cultivars, respectively. With respect to number of days for rooting initiation, Romero cultivar recorded 10.6 - 12.2 days, while Star cultivar recorded 11.4 - 13days.

\section{Effect of NAAand IBA concentrations}

Results presented in Table 5 show that, supplementing MS media with IBA at the rate of $1 \mathrm{mg} / \mathrm{l}$ significantly increased number of roots/ plantlet as well as average root length $(\mathrm{cm})$ compared with IBA at 1 or $1.5 \mathrm{mg} / 1$ significantly increased root formation (\%) with no significant differences between them. Results in the same table show that number of days for rooting initiation recorded minimum values $(6.5-7.5$ day) by adding IBA to MS media at the rate of 1 $\mathrm{mg} / \mathrm{l}$ which recorded $(8.5-10$ day $)$ in this respect.

IBA is one of the most commonly used plant growth regulator which used for root induction in watermelon (Krug et al., 2005; Thakur et al., 2005) had found that full strength MS media 
Zagazig J. Agric. Res., Vol. 47 No. (3) 2020

Table 3. Effect of the interaction between cultivars and benzyl adenine (BA) concentrations on growth of watermelon plantlets during multiplication stage

\begin{tabular}{|c|c|c|c|c|c|}
\hline Cultivar & $\begin{array}{c}\text { BA } \\
\text { concentration }\end{array}$ & $\begin{array}{l}\text { Shoot length } \\
\text { (cm) }\end{array}$ & $\begin{array}{c}\text { Number of } \\
\text { shoots/plantlet }\end{array}$ & $\begin{array}{c}\text { Number of leaves/ } \\
\text { plantlet }\end{array}$ & $\begin{array}{c}\text { Rooting } \\
\text { initiation (\%) }\end{array}$ \\
\hline \multirow{5}{*}{ Star Cv. } & $0.5 \mathrm{mg} \mathrm{BA} / \mathrm{l}$ & $4.58 \mathrm{c}$ & $7.33 \mathrm{~b}$ & $21.17 \mathrm{~g}$ & 100 \\
\hline & $1.0 \mathrm{mg} \mathrm{BA} / \mathbf{l}$ & $4.83 \mathrm{c}$ & $5.16 \mathrm{e}$ & $20.33 \mathrm{~h}$ & 100 \\
\hline & $1.5 \mathrm{mg} \mathrm{BA} / \mathrm{l}$ & $2.97 \mathrm{~d}$ & $7.55 \mathrm{a}$ & $20.11 \mathrm{i}$ & 100 \\
\hline & $2.0 \mathrm{mg} \mathrm{BA} / \mathrm{l}$ & $4.91 \mathrm{c}$ & $4.66 \mathrm{f}$ & $30.78 \mathrm{~b}$ & 100 \\
\hline & $4.0 \mathrm{mg} \mathrm{BA} / \mathrm{l}$ & $3.25 \mathrm{~d}$ & $4.50 \mathrm{f}$ & $32.50 \mathrm{a}$ & 100 \\
\hline \multirow{5}{*}{ Romero Cv. } & $0.5 \mathrm{mg} \mathrm{BA} / \mathrm{l}$ & $8.66 \mathrm{a}$ & $3.66 \mathrm{~h}$ & $25.67 \mathrm{c}$ & 100 \\
\hline & $1.0 \mathrm{mg} \mathrm{BA} / \mathbf{l}$ & $6.33 \mathrm{~b}$ & $6.00 \mathrm{~d}$ & $23.67 \mathrm{~d}$ & 100 \\
\hline & $1.5 \mathrm{mg} \mathrm{BA} / \mathrm{l}$ & $5.00 \mathrm{c}$ & $6.50 \mathrm{c}$ & $22.50 \mathrm{e}$ & 100 \\
\hline & $2.0 \mathrm{mg} \mathrm{BA} / \mathrm{l}$ & $7.25 \mathrm{~b}$ & $4.00 \mathrm{~g}$ & $25.67 \mathrm{c}$ & 100 \\
\hline & $4.0 \mathrm{mg} \mathrm{BA} / \mathrm{l}$ & $6.50 \mathrm{~b}$ & $3.33 \mathrm{i}$ & $21.33 \mathrm{f}$ & 100 \\
\hline
\end{tabular}

Table 4. Effect of cultivars on rooting formation characters of watermelon plantlets after four weeks of culture

\begin{tabular}{lcccc}
\hline Cultivar & $\begin{array}{c}\text { No. of roots/ } \\
\text { plantlet }\end{array}$ & $\begin{array}{c}\text { Average root } \\
\text { length }(\mathbf{c m})\end{array}$ & $\begin{array}{c}\text { Root formation } \\
(\%)\end{array}$ & $\begin{array}{c}\text { No. of days for } \\
\text { rooting initiation }\end{array}$ \\
\hline Star & $5.51 \mathrm{~b}$ & $3.84 \mathrm{~b}$ & $88.12 \mathrm{~b}$ & $11.4-13$ \\
Romero & $8.20 \mathrm{a}$ & $5.81 \mathrm{a}$ & $93.75 \mathrm{a}$ & $10.6-12.2$ \\
\hline
\end{tabular}

Table 5. Effect of different concentrations of auxins on rooting formation of watermelon plantlets after four weeks of culture

\begin{tabular}{cccccc}
\hline $\begin{array}{c}\text { Different concentrations } \\
\text { of auxins (mg/l) }\end{array}$ & $\begin{array}{c}\text { No. of roots/ } \\
\text { plantlet }\end{array}$ & $\begin{array}{c}\text { Average root } \\
\text { length }(\mathbf{c m})\end{array}$ & $\begin{array}{c}\text { Root formation } \\
(\%)\end{array}$ & $\begin{array}{c}\text { No. of days for } \\
\text { rooting initiation }\end{array}$ \\
\hline \multirow{4}{*}{$\mathbf{N A A}$} & $\mathbf{0 . 1}$ & $5.32 \mathrm{f}$ & $3.75 \mathrm{f}$ & $85.00 \mathrm{e}$ & $10.5-12.5$ \\
& $\mathbf{0 . 5}$ & $7.98 \mathrm{c}$ & $5.25 \mathrm{c}$ & $97.50 \mathrm{~b}$ & $6.5-7.5$ \\
& $\mathbf{1 . 0}$ & $5.95 \mathrm{e}$ & $5.25 \mathrm{c}$ & $95.00 \mathrm{c}$ & $10.5-11.5$ \\
& $\mathbf{1 . 5}$ & $4.24 \mathrm{~g}$ & $3.08 \mathrm{~g}$ & $80.00 \mathrm{f}$ & $16.5-18.5$ \\
$\mathbf{I B A}$ & $\mathbf{0 . 2}$ & $3.82 \mathrm{~g}$ & $4.06 \mathrm{e}$ & $77.50 \mathrm{~g}$ & $19-22$ \\
& $\mathbf{0 . 5}$ & $6.59 \mathrm{~d}$ & $4.40 \mathrm{~d}$ & $92.50 \mathrm{~d}$ & $10-11.5$ \\
& $\mathbf{1 . 0}$ & $10.87 \mathrm{a}$ & $6.85 \mathrm{a}$ & $100 \mathrm{a}$ & $6.5-7.5$ \\
& $\mathbf{1 . 5}$ & $10.06 \mathrm{~b}$ & $5.93 \mathrm{~b}$ & $100 \mathrm{a}$ & $8.5-10$ \\
\hline
\end{tabular}


supplemented with auxin induced high frequency in root formation. Ahn et al. (2007) reported that high frequency of shoots rooted and grew normally on MS media supplemented with IBA.

Effect of the interaction between watermelon cultivars and auxins concentrations

Results in Table 6 reveal that, adding IBA at $1 \mathrm{mg} / 1$ to MS medium of Romero cultivar was the superior interaction treatment which enhanced both number of roots/plantlet, average root length $(\mathrm{cm})$ compared with other interaction treatments. Furthermore, most of tested interaction treatments reflected a significant effect $(100 \%)$ with respect to root formation
$(100 \%)$. On the other hang adding IBA at the rate of $1.0 \mathrm{mg} / \mathrm{l}$ in MS medium of Star cultivar and adding NAA at the rate of $0.5 \mathrm{mg} / 1$ in MS medium of the other cultivar (Romero) were recorded the minimum values (6.7 days) with respect of number of days for rooting initiation. From the foregoing results, it could be concluded that supplementing IBA at 1 or 1.5 $\mathrm{mg} / \mathrm{l}$ to MS media were the best treatments for rooting stage of watermelon cultivars (Star and Romero). The highest percentage of rooting was achieved when medium was supplemented with $1.0 \mathrm{mg} / 1$ of indole-3-butyric acid (IBA) for the three genotypes (Surme, Beyazkis and Karakis) of watermelon (Okumus et al., 2011).

Table 6. Effect of the interaction between cultivars and different concentrations of auxins on rooting formation characters of watermelon plantlets after four weeks of culture

\begin{tabular}{|c|c|c|c|c|c|c|}
\hline$\overline{\text { Cultivar }}$ & $\begin{array}{r}\text { Differen } \\
\text { of a }\end{array}$ & $\begin{array}{l}\text { ntrations } \\
\mathrm{ng} / \mathrm{l})\end{array}$ & $\begin{array}{c}\text { No. of roots/ } \\
\text { plantlet }\end{array}$ & $\begin{array}{l}\begin{array}{c}\text { Average root } \\
\text { length }(\mathrm{cm})\end{array} \\
\end{array}$ & $\begin{array}{c}\text { Root } \\
\text { formation (\%) }\end{array}$ & $\begin{array}{c}\text { No. of days for } \\
\text { rooting initiation }\end{array}$ \\
\hline \multirow{8}{*}{ Star } & \multirow{4}{*}{ NAA } & 0.1 & $4.55 \mathrm{~g}$ & $3.30 \mathrm{hi}$ & $80 \mathrm{e}$ & $11-13$ \\
\hline & & 0.5 & $6.97 \mathrm{~d}$ & $4.41 \mathrm{f}$ & $95 \mathrm{~b}$ & $7-8$ \\
\hline & & 1.0 & $5.21 \mathrm{f}$ & $4.40 \mathrm{f}$ & $90 \mathrm{c}$ & $11-12$ \\
\hline & & 1.5 & $3.69 \mathrm{hi}$ & $2.67 \mathrm{j}$ & $75 \mathrm{f}$ & $18-20$ \\
\hline & \multirow{4}{*}{ IBA } & 0.2 & $3.37 \mathrm{i}$ & $3.12 \mathrm{i}$ & $75 \mathrm{f}$ & $20-22$ \\
\hline & & 0.5 & $4.95 \mathrm{fg}$ & $3.65 \mathrm{~g}$ & $90 \mathrm{c}$ & $10-12$ \\
\hline & & 1.0 & $8.25 \mathrm{c}$ & $4.86 \mathrm{e}$ & $100 \mathrm{a}$ & $6-7$ \\
\hline & & 1.5 & $7.13 \mathrm{~d}$ & $4.32 \mathrm{f}$ & $100 \mathrm{a}$ & $8-10$ \\
\hline \multirow{8}{*}{ Romero } & \multirow{4}{*}{ NAA } & 0.1 & $6.10 \mathrm{e}$ & $4.20 \mathrm{f}$ & $90 \mathrm{c}$ & $10-12$ \\
\hline & & 0.5 & $9.00 \mathrm{~b}$ & $6.10 \mathrm{c}$ & $100 \mathrm{a}$ & $6-7$ \\
\hline & & 1.0 & $6.70 \mathrm{de}$ & $6.10 \mathrm{c}$ & $100 \mathrm{a}$ & $10-11$ \\
\hline & & 1.5 & $4.80 \mathrm{fg}$ & $3.50 \mathrm{gh}$ & $85 \mathrm{~d}$ & $15-17$ \\
\hline & \multirow{4}{*}{ IBA } & 0.2 & $4.27 \mathrm{gh}$ & $5.00 \mathrm{de}$ & 80 e & $18-22$ \\
\hline & & 0.5 & $8.24 \mathrm{c}$ & $5.16 \mathrm{~d}$ & $95 \mathrm{~b}$ & $10-11$ \\
\hline & & 1.0 & $13.50 \mathrm{a}$ & $8.85 \mathrm{a}$ & $100 \mathrm{a}$ & $7-8$ \\
\hline & & 1.5 & $13.00 \mathrm{a}$ & $7.55 \mathrm{~b}$ & $100 \mathrm{a}$ & $9-10$ \\
\hline
\end{tabular}




\section{REFERENCES}

Ahn, Y.J., L. Vang, T.A. Mckeon and G.O. Chen (2007). Hight frequency plant regeneration through adventitious shoot formation in castor (Ricinus communis L.). In vitro Cell. Dev. Biol. Plant., 43:9-15.

Compton, M.E. and D.J. Gray (1993). Shoot organogenesis and plant regeneration from cotyledons of diploid, triploid, and tetraploid watermelon. J. Ame. Soc. Hort. Sci., 118 : 151-157.

Compton, M.E. and D.J. Gray (1994). Adventitious shoot organogenesis and plant regeneration from cotyledons of tetraploid watermelon. Hort. Sci., 29: 211 -213.

Cortina, C. and A. Culiáñez-Macià (2004). Tomato transformation and transgenic plant production. Plant Cell Tissue and Organ Culture, 76 (3): 269-275.

Dabauza, M., M. Bordas, A. Salvador and L.A. Roig (1997). Plant regeneration and Agrobacterium-mediated transformation of cotyledon explants of Citrullus colocynthis (L.) Schrad. Plant Cell Reports, 16 : 888-892.

Dong, J. and S. Jia (1991). High efficiency plant regeneration from cotyledons of watermelon (Citrullus vulgaris Schrad.). Plant Cell Reports, 9 : 559-562.

Duncan, D.B. (1955). Multiple Range and Multiple F-Test. Biometrics, 11:1-5.

Khalequzzaman, K.M., M.M. Rashid, M.A. Hasan and M.A. Reza (2012). Effect of storage containers and storage periods on the seed quality of french bean (Phaseolus vulgaris) Bangladesh J. Agric. Res., 37: 2.

Krug, M.G.Z., L.C.L. Stipp, A.P.M. Rodriguez and B.M.J. Mendes (2005). In vitro organogenesis in watermelon cotyledons. Pesquisa Agropecuaria Brasileira, Brasilia, 40: 861-865.

Murashige, T. and F. Skoog (1962). A revised medium for rapid growth and bio-assays with tobacco tissue cultures. Physiol. Plant, (15): $473-497$.

Okumuş, V., B. Dogan, O. Ahmet and V. Pirinç (2011). In vitro propagation of diyarbakır watermelons and comparison of direct seeded and transplanted watermelon. Turkish J. Biol., 35: 601-610

Snedecor, G.W. and W.G. Cochran, (1980). Statistical Methods. $7^{\text {th }}$ Ed., Iowa State Univ. Press, Ames.

Srivastava, D.R., V.M. Andrianov and E.S. Pi'ruzian (1989). Tissue culture and plant regeneration of watermelon (Citrullus vulgsris Schrad. Cv. Melitopolski). Plant Cell Rep., 8: 300-302.

Sultana, R.S. and M.A. Bari (2003). Effect of different plant growth regulators on direct regeneration of watermelon (Citrullus lanatus Thumb.). Plant Tissue Culture, 13 (2): 173-177.

Thakur, A.K., S. Sharma and D.K. Srivastava (2005). Plant regeneration and genetic transformation studies in potiole tissue of Himalayan poplar (Populus ciliate Wall.). Curr. Sci., 89: 664-668. 


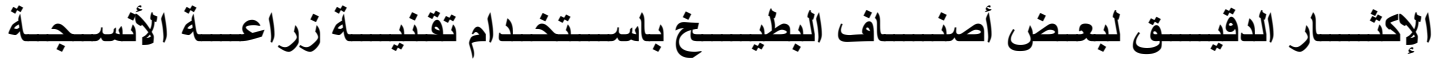

مها صبر ي عامر - حامد محمد الهادي عريشة ـ عبد الله برديسي ـ داليا أحمد سامي نوار

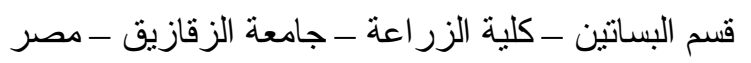

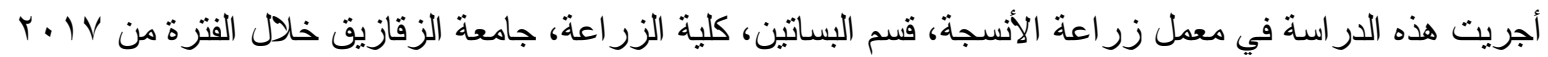

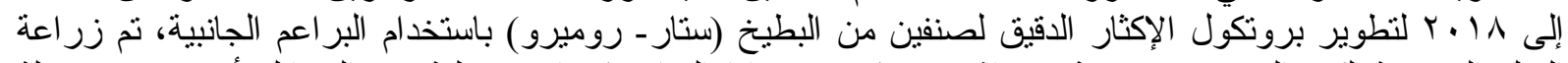

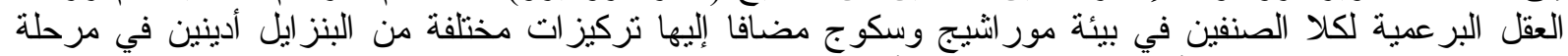

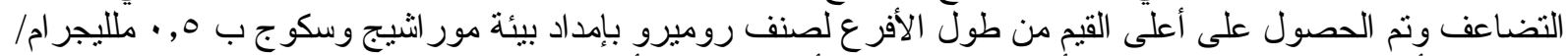

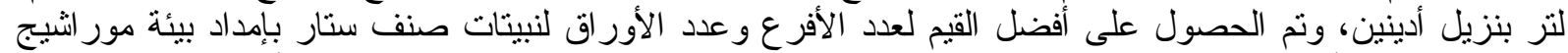

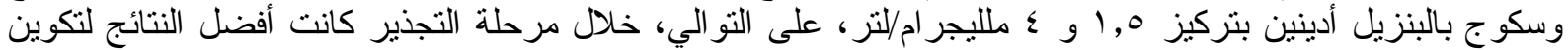

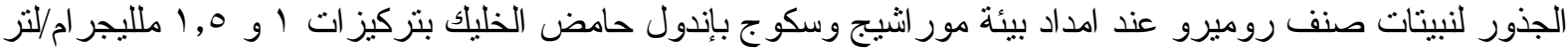

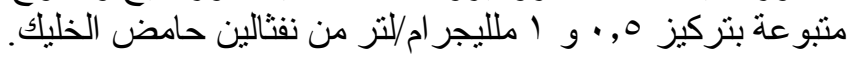

